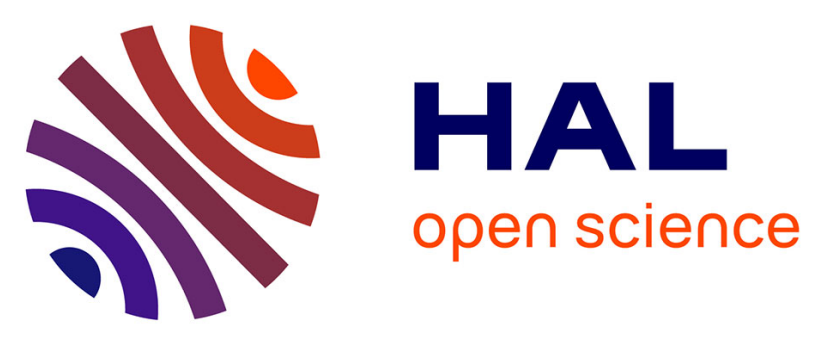

\title{
An Ontology-based Algorithm for Managing the Evolution of Multi-Level Territorial Partitions
}

Camille Bernard, Christine Plumejeaud-Perreau, Marlène Villanova-Oliver, Jérôme Gensel, Hy Dao

\section{- To cite this version:}

Camille Bernard, Christine Plumejeaud-Perreau, Marlène Villanova-Oliver, Jérôme Gensel, Hy Dao. An Ontology-based Algorithm for Managing the Evolution of Multi-Level Territorial Partitions. 26th ACM SIGSPATIAL International Conference on Advances in Geographic Information Systems (ACM SIGSPATIAL 2018), Nov 2018, Seattle, WA, United States. , 2018, 10.1145/3274895.3274944 • hal01929649

\section{HAL Id: hal-01929649 \\ https://hal.science/hal-01929649}

Submitted on 21 Nov 2018

HAL is a multi-disciplinary open access archive for the deposit and dissemination of scientific research documents, whether they are published or not. The documents may come from teaching and research institutions in France or abroad, or from public or private research centers.
L'archive ouverte pluridisciplinaire HAL, est destinée au dépôt et à la diffusion de documents scientifiques de niveau recherche, publiés ou non, émanant des établissements d'enseignement et de recherche français ou étrangers, des laboratoires publics ou privés. 

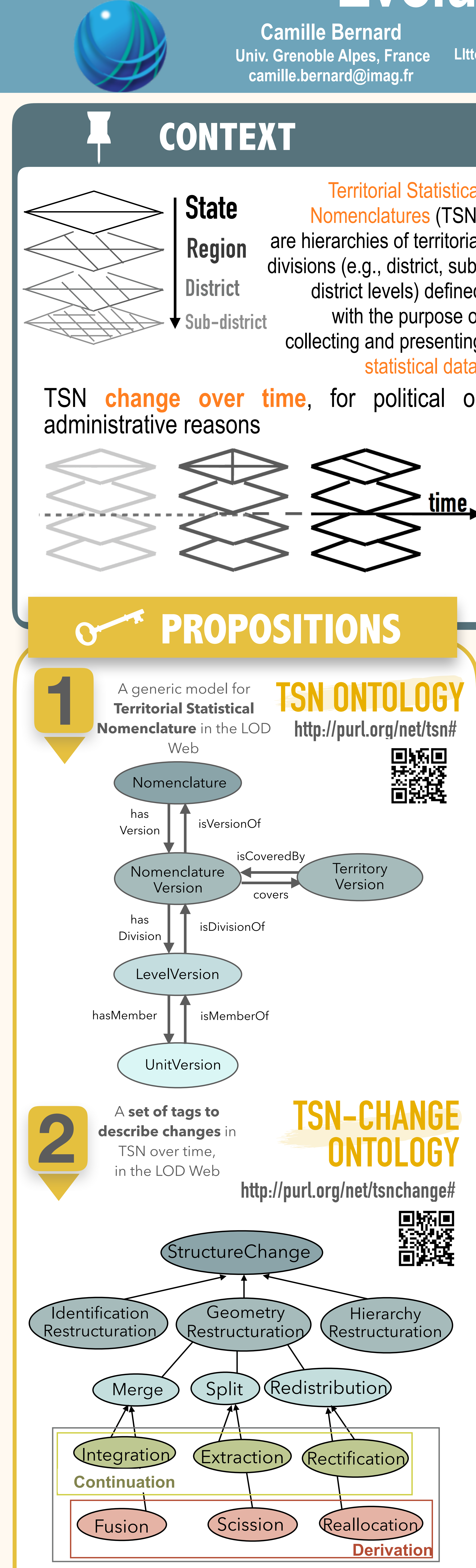

A graph structure to navigate
through the TSN versions + observe the propagation of a CHANGE change event through the levels

BRIDGES

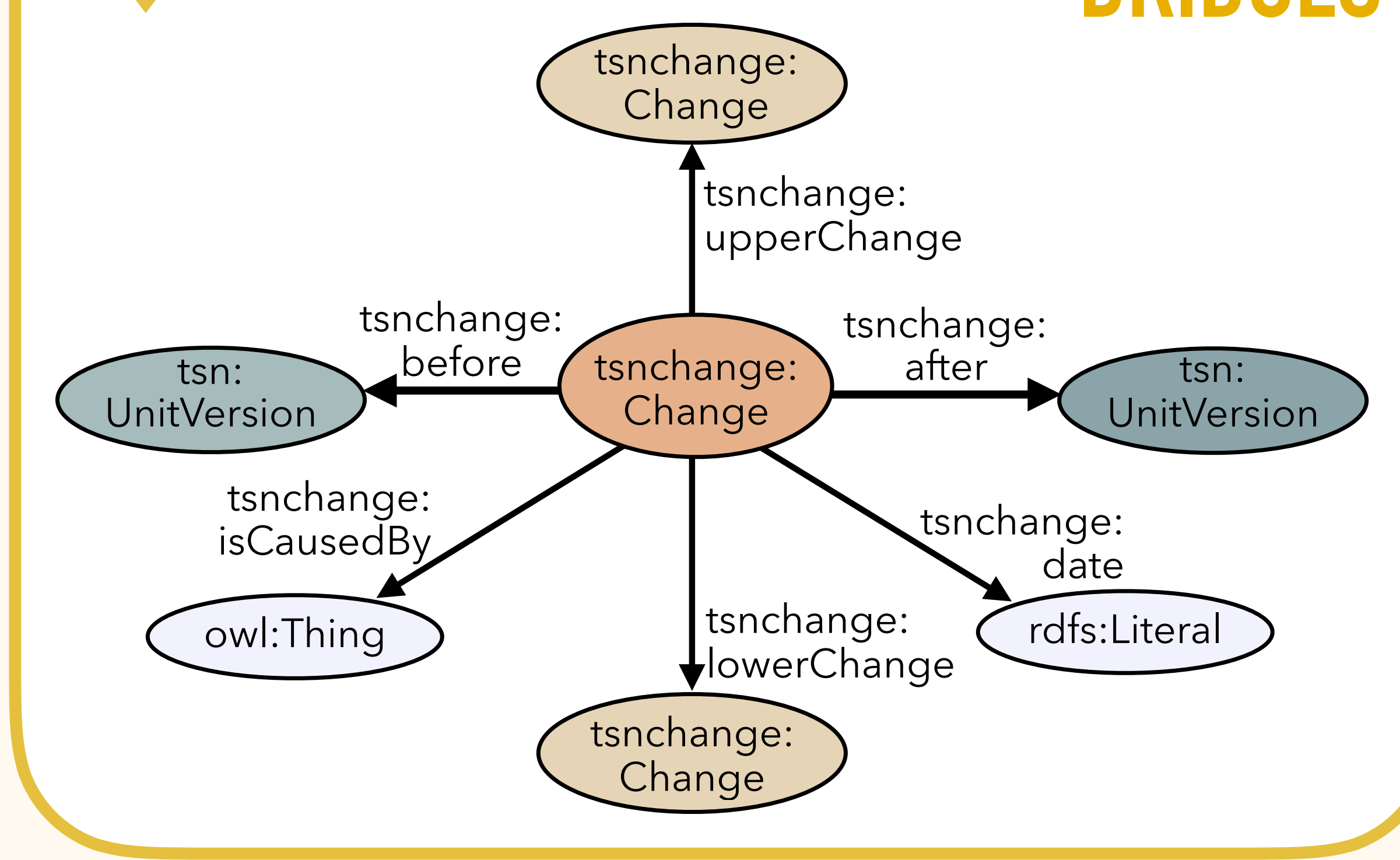

\subsection{Identifying clusters of changes}

Builds through iterations two sets of units Before $K$ and Afterk. Adds successively to the sets, units that intersect ones in the other version. Stops when one set (BeforeK or AfterK) remains identical between two iterations.

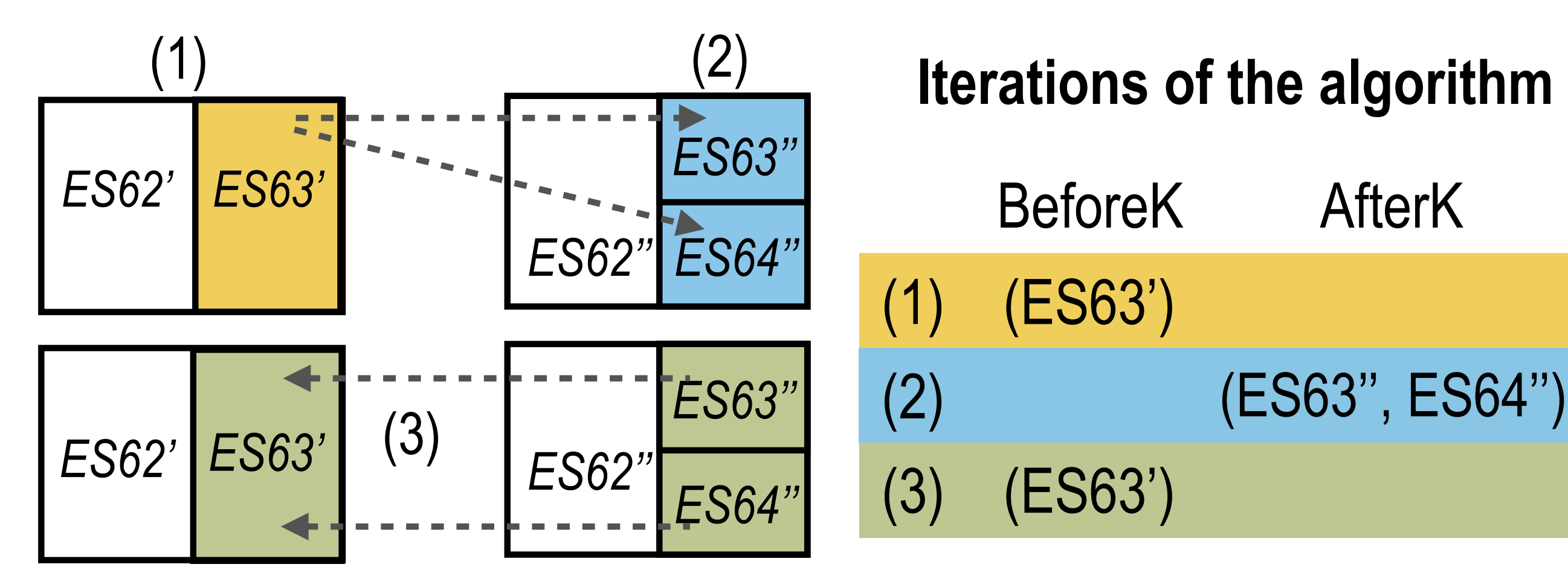

Uses relations between units in order to link changes through the TSN levels

\section{RESULTS}

\subsection{Linking changes through the levels \\ .3 Structurechange output}

Solution - configurable identity test in 3 steps:

1. An expert defines which attributes hold the identity of the units ID? Name? Geom? Super Unit?

2. For each attribute: a specific Comparison Operator is defined to measure distance between the two versions:

3. Coefficients $\alpha_{k}$ assigned to attributes = define in which proportion attributes can vary before unit loses its identity. E.g $F\left(\alpha_{1}\right.$, identifier $),\left(\alpha_{2}\right.$, geom $),\left(\alpha_{3}\right.$, name $)$ where $\alpha_{1}=1 / 3, \alpha_{2}=1 / 3, \alpha_{3}=1 / 6$ $1 / 3 *\left(\mid u^{\prime}\right.$. identifier $-u^{\prime \prime}$. identifier $\left.\mid\right)+$

$1 / 3 *\left(\mid u^{\prime}\right.$.geom $-u^{\prime \prime}$.geom $\left.\mid\right)+1 / 6 *\left(\mid u^{\prime}\right.$. name $-u^{\prime \prime}$. name $\left.\mid\right)$

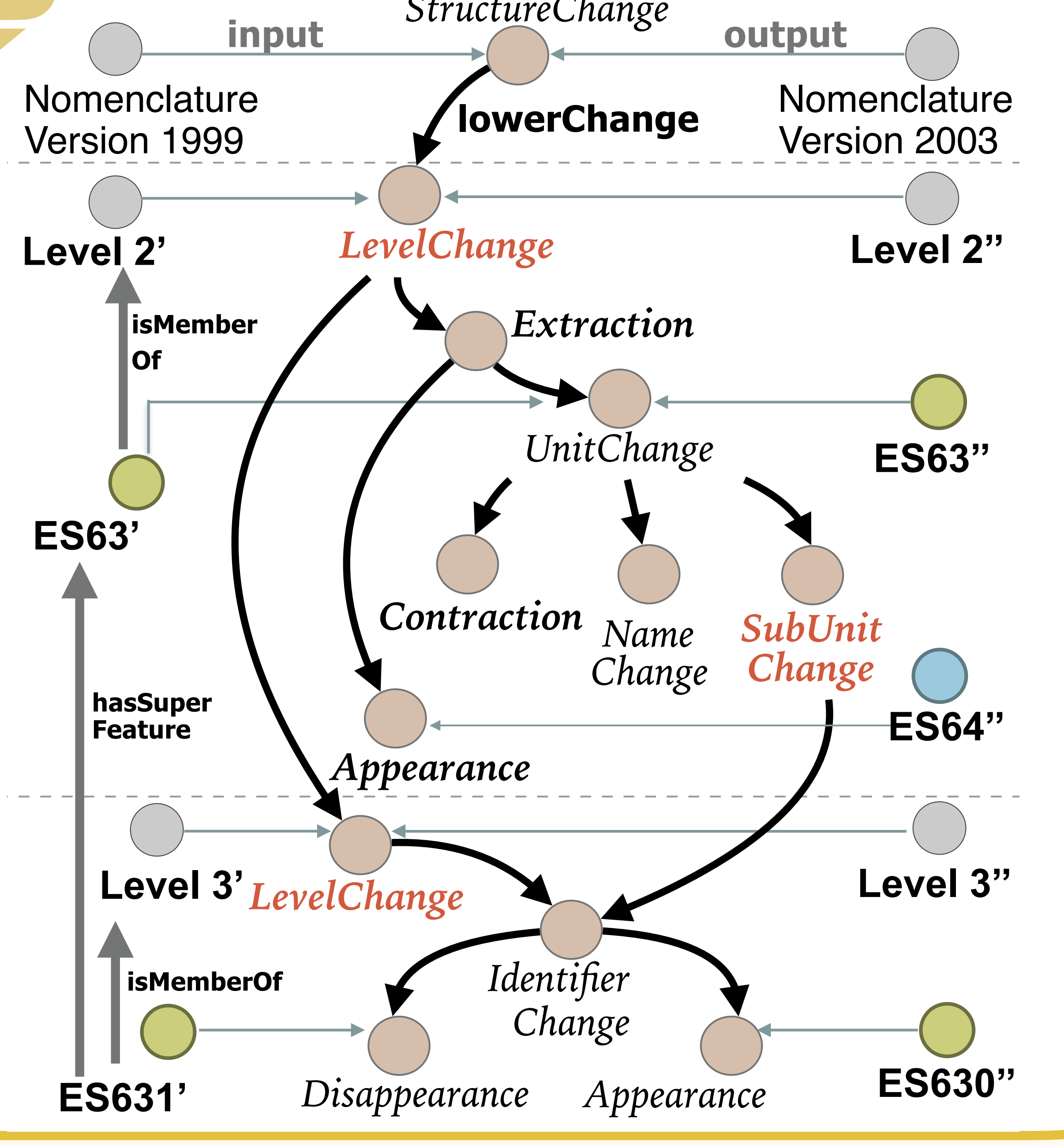

Automatize detection \& semantic description of TSN changes: feature by feature + cluster of changes + chain of changes + 2 case studies

$\checkmark$ Europe - Nomenclature of Territorial Units for Statistics (NUTS)

4 versions, 4 levels, 7619 geographic units

WHAT'S NEXT?

122,000 resources describing European Units

39,306 resources describing matching and changes

http://purl.org/steamer/nuts 